\title{
FRANCES MARION AND MARY PICKFORD
}

\author{
A Thesis \\ Presented to \\ The Faculty of California Polytechnic State University, \\ San Luis Obispo \\ In Partial Fulfillment \\ Of the Requirements for the Degree \\ Master of Arts in History \\ by \\ Christopher Zeidel \\ March 2009 \\ (C) 2009 \\ Christopher Zeidel
}


All Rights Reserved

COMMITTEE MEMBERSHIP

TITLE:

Frances Marion and Mary Pickford 

AUTHOR:
Christopher Zeidel
DATE SUBMITTED:
March 2009

COMMITTEE CHAIR: Thomas R. Trice, Associate Professor

COMMITTEE MEMBER: Kathleen Cairns, Part Time Lecturer

COMMITTEE MEMBER: John G. Snetsinger, Part Time Lecturer

\author{
ABSTRACT \\ Frances Marion and Mary Pickford \\ Christopher Zeidel
}


This thesis attempts to find out how Frances Marion and Mary Pickford survived the film industry by having a strong working relationship. It is revealed through letters, films, autobiographies, and newspapers that Marion and Pickford were good friends and had worked closely together for years. Their friendship helped them to work hard enough to continue making films between the late 1910s and 1920s. Unfortunately, this topic is challenging because there has not been enough historical work done to give us a completely clear and accurate picture of how Marion and Pickford helped one another to continue working in the movie industry. More information is available on their careers that have nothing to do with their relationship. There were ways in which they struggled to work and reasons for why they survived the industry that have nothing to do with their working relationship. 


\section{CHAPTER}

I.

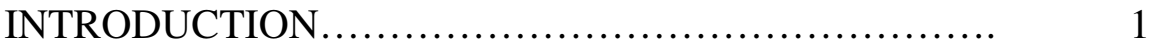

II. $\quad$ CHAPTER 1: HISTORIANS ............................ 7

III. $\quad$ CHAPTER 2: THE LETTERS........................... 24

IV. $\quad$ CHAPTER 3: THE FILMS .............................. 33

V. CHAPTER 4: THE HARD WORK OF FILMMAKING..... 50

VI. $\quad$ CHAPTER 5: NEWSPAPERS........................... 55

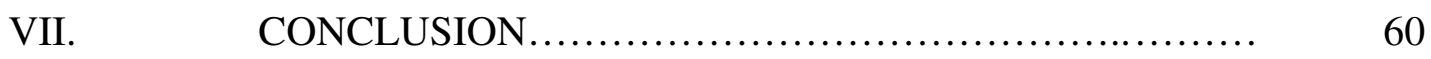

VIII. BIBLIOGRAPHY ................................... 65 


\section{Introduction}

The film industry in the early years of cinema was not entirely dominated by men. Film historians or anyone interested in cinema history have understood that women made powerful and significant contributions to acting and screenwriting between the 1910s and early 1930s. They will have familiarized themselves with Mary Pickford and screenwriter Frances Marion, and how they became the most influential women in the film industry during the silent era. It is safe to assume that Pickford and Marion did not have an easy time competing with men for success in the film business. It is no doubt that a woman had difficulty gaining clout in a new industry that could be exclusively controlled by men and where women could easily become marginalized.

Historians have given several reasons for why Pickford became a powerful and popular figure in show business. Some of those reasons have to do with her personality, business knowledge, and that she was appealing to the general public. It is necessary to note that women have benefited in both their professional and personal lives by having close ties with one another. Women have developed friendships among each other to cope with the hardships of life, and especially in dealing with male domination over society. Pickford and Marion developed a close relationship and became best friends. One must consider that they achieved success by being friends and helping one another get through a difficult industry. The purpose of this paper is to show how their friendship helped them survive the business. Women started to enter all aspects of the film industry when it was new. Marion and Pickford were among these women. They built strong careers in show 
business and worked closely together. More importantly, they were able to continue working in the film industry during the late 1910s and 1920s. This is partially because they helped one another survive it. This thesis examines the relationship between Frances Marion and Mary Pickford. It looks at how Marion and Pickford were close at times, but more distant at other times. It shows how women were able to help build each other's lives in ways that could enable them to survive the difficulties of life.

There has been a positive and a negative side to doing research on this topic. Several sources that include correspondence, films, and written works by Pickford and Marion have been helpful in understanding their relationship. Historians have focused on how Pickford and Marion were knowledgeable about filmmaking and the movie industry. They have also written about their individual achievements. Unfortunately, some of these historians have had a surprising lack of interest concerning the relationship between Pickford and Marion and did not do work on the subject. There are other sources like newspaper articles that are not entirely clear about their relationship, although it is important to point out that the news articles are useful in certain ways. This paper will examine letters, some writings by Pickford and Marion, films, works by historians including dissertations, and newspaper articles to show how much work has been done on this topic and what is available.

The most useful sources are the letters exchanged between Pickford and Marion. The letters did not come from the period between the late 1910s and early 1930s when they were working in the industry. Since Pickford and Marion worked in the same business and made several films together, one can say that 
they frequently saw each other and would not often need to exchange letters. The letters written by the two women were done between the 1960s and the early 1970s. Although the Writer's Guild of America honored Marion near the end of 1972, she and Pickford were no longer involved with the film industry by the 1960s and 1970s. They did not have as many opportunities to see one another by the 1960s. It became impossible sometimes for them to visit each other due to old age and health problems. The letters are helpful, however. They reveal that their friendship was strong and deep, how much they loved and supported each other, and also give us ideas about how they had strengthened each other's careers.

Writings by Pickford and Marion are also helpful. Marion was a talented screenwriter, which helped her get connected to influential people such as Mary Pickford and William Randolph Hearst. Marion was able to build a professional and personal relationship with Pickford because she was talented. It was her abilities as a screenwriter that helped them fight their way through a tough industry. Her book called How To Write and Sell Film Stories shows that she was knowledgeable about screenwriting. Marion discusses how screenwriters are supposed to write screenplays and how they can get their scripts sold. It illustrates that she survived the business by having mastered all the lessons of screenwriting. She learned to be strong and confident as a writer and as a businesswoman. Marion helps us understand her working relationship with Pickford in her memoirs Off With Their Heads. Pickford also had some valuable things to say about her experiences in the movie industry, which she does in her autobiography Sunshine and Shadow. 
Perhaps even more helpful are the films that Pickford and Marion made together such as Amarilly of Clothes-Line Alley, Rebecca of Sunnybrook Farm, and The Love Light. Marion wrote and directed The Love Light. Since Marion and Pickford were very close, they probably shared beliefs about life, human nature, and the world. These films may clarify their relationship by helping us understand their attitudes about the world. They would also show that Marion and Pickford fought hardships together by expressing those ideas in their films.

A vital question is how much work historians have done on the relationship between Pickford and Marion. A significant portion of women's history is how they have related to each other. It is necessary to study the relationships between women to understand how they fought for equality with men such as the women's suffrage movement, and the roles they played in other social and political causes like abolition of slavery, temperance, and civil rights. The professional and personal relationships between women, as in the case of Pickford and Marion, could also explain how women survived competitive working environments alongside men. Historians have of course studied and written about Pickford and Marion. Have they done enough work for us to understand the relationship between Pickford and Marion? Many historians have been conservative in how they have written about the two women. Historians have written about the subject in a traditional way. They have discussed how Pickford and Marion worked in the industry without delving into the possibility that their relationship was a benefit to their careers. Historians like Debra Steidel have written about Pickford's career playing little girl roles without exploring the relationship between her and 
Marion. ${ }^{1}$ Other historians like Lizzie Francke briefly mention the relationship between Marion and Pickford, but are still more interested in how Marion wanted to do other jobs besides screenwriting. ${ }^{2}$ Historians such as Wendy Holliday have written about Marion's success as a screenwriter during the 1920s. ${ }^{3}$ Even though historians have discussed the two women separately, it is still possible to see from some historical work, like that of Cari Beauchamp, how Pickford and Marion related to one another. Cari Beauchamp's Without Lying Down gives us the clearest picture of the working relationship between Pickford and Marion.

Newspaper articles are not completely clear about the relationship between Pickford and Marion. They require heavier examination to get an idea of how their friendship helped them survive the film industry. Newspaper articles are still useful, however. It is arguable that their friendship helped them become important and influential figures in the film industry from the 1910s to the 1930s. It is also possible that their relationship had become beneficial to them when they did not work together. Close examination of news articles may show that their relationship was strengthened because they had similar experiences. Pickford and Marion shared the experiences of having contributed greatly to the film industry, becoming successful filmmakers, having an impact on the general public, and basically being important and influential figures of early cinema. Marion and Pickford provided the public with moral lessons through their films, and they perhaps shared views about people and life. Pickford and Marion would not say

\footnotetext{
${ }^{1}$ Debra Eve Steidel, "That Her Soul May Remain Pure: Women In American Silent Film," (M.A. diss., The American University, 1989), 88-90.

${ }^{2}$ Lizzie Francke, Script Girls-Women Screenwriters In Hollywood (London, British Film Institute Publishing, 1994), 41.

${ }^{3}$ Wendy Holliday, "Hollywood's Modern Women: Screenwriting, Work Culture, and Feminism, 1910-1940," (diss., New York University, May 1995), 120.
} 
this brought them success. Some sources do reveal that Marion and Pickford survived the film industry because they worked well and hard together as is evident from the productions of Rebecca of Sunnybrook Farm and A Poor Little Rich Girl.

\section{Chapter 1: Historians}

There has been a surprising lack of historical work to address the relationship between Pickford and Marion. Historians focusing on film and women's history have of course commonly written about Pickford. It is puzzling, however, that 
historians have paid little attention to the relationship between Pickford and Marion. It appears that Marion played a significant role in Pickford's career. She helped to create some of Pickford's most successful films. The leading expert on this topic is Cari Beauchamp. Beauchamp shows in her book Without Lying Down that Marion understood Pickford's childhood problems. Beauchamp explains that Marion had therefore written little girl parts that were not only right for Pickford, but also strengthened her acting career. Although Cari Beauchamp gives us an idea of how the relationship between Marion and Pickford helped them survive the industry, she cannot be solely relied upon. It should thus be necessary to see what other historians have said about the relationship between Pickford and Marion and how they helped each other professionally. Perhaps other historians would have ideas about the relationship between Marion and Pickford that Beauchamp fails to examine. Maybe there are historians who would disagree with Beauchamp, or others that may argue that there is not sufficient information available to help us get a clear idea about how Marion and Pickford helped one another survive the movie industry. The problem is that historians have paid little attention to this issue. They have either not explored it deeply enough, or simply directed their attention elsewhere. Debra Eve Steidel explored Pickford's issue with childhood in her dissertation That Her Soul May Remain Pure. Unlike Beauchamp, Steidel ignores Marion's role in the matter. Wendy Holliday in her dissertation titled Hollywood's Modern Women focuses more on Marion and how difficult it was for women to be screenwriters during the 1910s. Karen Ward Maher in her dissertation called Women, Filmmaking, and the Gendering of the American Film Industry goes further into how women like Marion entered 
screenwriting during the 1910s and 1920s. Lizzie Francke discussed in her book entitled Script Girls the difficulties Marion faced in trying to build a career in Hollywood, but does not go deeply into how Pickford affected her career. Eileen Whitefield briefly discussed the working relationship Pickford had with Marion on The Love Light, but she ultimately thinks it is more significant that the film's subject matter failed to interest audiences. Marjorie Rosen Coward in her book Popcorn Venus argues that audiences were more attracted to the films in which Pickford played little girls because of their strong belief that young girls were angelic. Coward does not focus on Pickford's relationship with Marion because she believes that Pickford's own pure image was more important. Ally Acker argues in Reel Women that the most important aspect of Pickford's career was her shrewdness. Like Marjorie Coward, Gaylyn Studlar was more interested in how audiences responded positively towards Pickford's child roles. Studlar's article called Oh, “Doll Divine” ignores Marion's contribution to these roles. Sean P. Holmes argues in his article The Hollywood Star System and the Regulation of Actor's Labor that the most significant aspect of Pickford's career was her push to protect her rights as an actress from an industry that gave producers too much power.

It is important to see what historians have had to say about the professional relationship between Mary Pickford and Frances Marion. The most noteworthy is Cari Beauchamp, who has written about how Marion affected Pickford both professionally and personally. Cari Beauchamp points out in her book Without Lying Down, that Marion was important to Pickford's career. Pickford said that Marion had been the "pillar" of her career, according to Beauchamp. Marion had 
written Pickford's most successful films such as Rebecca of Sunnybrook Farm, Pollyanna, and A Little Princess, so it becomes clear that she was the one that strengthened Pickford's career and was her biggest support. Beauchamp states that Pickford did not have a real childhood when growing up. She had to act and almost live like an adult when she was a child. Pickford was more like a mother to her family than one of the children. She was her family's provider and had all the responsibilities of one. Marion understood how Pickford was affected by her childhood. Beauchamp shows that Marion wrote little girl roles for Pickford so that Pickford could learn what it is like to be a child. Pickford's only opportunity to experience childhood was in playing little girls, and Marion gave her this chance by writing such films as Rebecca of Sunnybrook Farm and A Little Princess. Pickford was cast as a child in Rebecca of Sunnybrook Farm, which enabled Marion to help Pickford understand the joys and innocence of childhood. Marion did this by adding things into the script from her own childhood, such as the time she and her friends made a zoo at her father's resort and painted a cow black and white to look like a zebra. While stories of Marion's childhood made Pickford laugh, they made her sob too. These tales made Pickford think about how she had been "the most miserable kid in the world." Pickford meant by this statement that she did not have a happy life as a child. It can be said that Pickford played little girls to do away with these miserable feelings and experience childhood and its joys for the first time. Beauchamp notes that Marion and Pickford were hoping that Rebecca of Sunnybrook Farm would become a hit. It indeed became a huge success. A Little Princess premiered on November 5, 1917 at the Strand Theater. The theater was packed on its opening night, and Pickford 
received rave reviews for her "flawless" performance. Pickford's desire to experience childhood through her film roles made her believe strongly in her work. It made Pickford work hard to make her films like Rebecca of Sunnybrook Farm and A Little Princess successful. Marion helped Pickford achieve success. She wrote parts that allowed Pickford to experience childhood. Pickford gave the best possible performances as little girls because of her desire to be a child. Pickford's desire to give great performances could have been one reason for why some of her films were successful. Beauchamp shows that Rebecca of Sunnybrook Farm helped get her career back on track after it had gone through a less productive period, and that A Little Princess led critics to give her good reviews for her acting. ${ }^{4}$

In putting Pickford's Sunshine and Shadow into consideration, she becomes more complex and even contradictory. It seems with Rebecca of Sunnybrook Farm about a little girl who learns the value of helping others that Pickford wanted to discover the joys of childhood that were not present in her own upbringing. ${ }^{5}$ In making Pollyanna, it appears that she desired to play a character that was like her. Judging from Beauchamp, it seems Mary did not have a nice childhood and that there was nothing pure or saintly about it. Pickford shows in Sunshine and Shadow that she did not like Pollyanna because her character was dissimilar to herself. Pollyana is about another saintly girl. Unlike Mary, Pollyanna was wholesome and lived in a pure world. ${ }^{6}$ It is possible that Mary

\footnotetext{
${ }^{4}$ Cari Beauchamp, Without Lying Down (Berkeley, University of California Press, 1997), 9, 72, 80-81.

${ }^{5}$ Marshal Neilan's Rebecca of Sunnybrook Farm.

${ }^{6}$ Mary Pickford, Sunshine and Shadow (Garden City New York, Doubleday and Company, Inc., 1955), 191-194.
} 
would have liked her audiences to accept her in child roles that lacked purity like she had when growing up. It is probably not fair to say that Mary was contradictory. Rebecca of Sunnybrook Farm was released in 1917 and Pollyanna came out in 1920. Mary could have changed her thinking and attitude during those three years.

Debra Eve Steidel's 1989 dissertation titled That Her Soul May Remain Pure: Women In American Silent Film does a good job at defining Mary Pickford, and her attitude towards childhood. It suggests that Mary wanted her audiences to see her play little girls that were uncorrupted, and that she was pure as a child. Steidel shows that Mary Pickford used her film roles to stay young. Debra Steidel illustrates that Pickford told the press that she was forced to live as an adult during her childhood, but was intending to remain young. According to Steidel, Pickford tried to be young by choosing to play "good girls" that were "sweet" and "sunny." Steidel noted on the other hand, that Mary's films conveyed the hardships of childhood. They tackle issues like orphaning, adoption, evil stepparents, children having to deal with overwhelming changes like instantly becoming rich or poor, and children that are unhappy at home and desire to run away. Steidel shows that Mary played girls that were moral, and who fought against injustices to make people happy. Her characters were heroic girls with creative ways to help people. They gave younger people "maternal love, affection, and guidance," as Steidel states. Debra Steidel points out that Mary's characters appealed to women that were dependent on men. The courageousness of Mary's characters would certainly appeal to women that were unhappy for having to depend on their husbands and who fantasized about being bold individuals. This 
suggests that Mary was a good and pure child, but was harmed by some form of injustice. She desired to fight against whatever violated the rights of her family and herself. Mary Pickford's public image was of a girl that was pure, but struggled against corruption. ${ }^{7}$

Debra Steidel's dissertation explores Mary Pickford's films, including the ones she made with Frances Marion like The Little Princess and Rebecca of Sunnybrook Farm. The problem is that Steidel does not mention Frances Marion, which is a problem with many historians writing about film and women. It can still be said that Frances Marion helped Mary develop her image of a pure girl that fought injustice. Frances wrote courageous characters for Mary. These characters appealed to women because they were bold as Steidel pointed out. This helped to make Pickford's films successful.

Frances Marion is discussed in Wendy Holliday's 1995 dissertation called Hollywood's Modern Women: Screenwriting, Work Culture, and Feminism, 19101940. Holliday states that Frances Marion chose not to continue with a boring career in journalism. Frances developed a desire to write a screen scenario. Her professional life changed drastically, but in a positive way after she wrote her first scenario. Frances sold the scenario to Mary Pickford, which led her to become one of the most respected and extremely well paid screenwriters in Hollywood. ${ }^{8}$ Holliday does not explore Frances Marion's working relationship with Mary Pickford, but she focuses on why it was difficult for women to work as screenwriters in early Hollywood and how they eventually became successful.

\footnotetext{
${ }^{7}$ Debra Eve Steidel, "That Her Soul May Remain Pure: Women In American Silent Film," 88-90.

${ }^{8}$ Wendy Holliday, "Hollywood's Modern Women: Screenwriting, Work Culture, and Feminism, 1910-1940," 120.
} 
The reason for why women achieved success as screenwriters may show why Mary Pickford supported Frances Marion's work, especially in purchasing her first screenplay.

According to Wendy Holliday, women had difficulty entering several professions during the 1910s and 1920s. These professions included law, medicine, and journalism, which throughout history had excluded women and were dominated by men. Screenwriting was new in the 1910s. Famous literary writers tried to write for the screen but failed. They felt that producers did not understand literature, and complained that filmmakers including screenwriters and directors were altering their work. The studios felt that these writers did not take film seriously, and intentionally sent the movie industry poor work. The failure of famous literary writers to write for the screen, led to the idea that screenplays should be written by men who were not famous, were good writers, and would be interested in the film business. Wendy Holliday states, however, that professional writers viewed screenwriting as an illegitimate profession that should be ridiculed, avoided, and hidden. Holliday points out that actress Gene Gauntier had recalled that screenwriters during the early period of film were unknown because they were not credited for their work. Gauntier had further stated that screenwriters were poorly paid. The idea is that men should pursue careers that would allow them to work as professionals. Screenwriting became an amateur occupation in the 1910s. Men therefore would be disinterested in having careers as screenwriters. Since screenwriting was an amateur job, it seemed more suitable for women. ${ }^{9}$ Women that were struggling to go into the workplace and trying to

\footnotetext{
${ }^{9}$ Ibid., 112-113, 117-119.
} 
build professional careers would certainly find screenwriting difficult since it paid low and writers were not being acknowledged for their work.

According to Wendy Holliday, Frances Marion became a screenwriter unwillingly. Frances believed that screenwriting had a low status in the 1910s because women dominated it. She also did not like the idea of working as a scenario writer when writing her first script because the pay was poor, and screenwriters were not appreciated for their talent. Screenwriters were treated like they were unimportant and not allowed to have any power or influence. This shows that Frances desired a profession that paid well, and where she could have some influence rather than being "pushed to the background" like screenwriters had been. Screenwriting did develop from amateur work into a professional job, which benefited women. Men did screenwriting as a side job just to earn around ten or twenty dollars an easy way. The rest of the screenwriters were women. Wendy Holliday states that women in other professions struggled with male competition, which made it difficult for them to succeed. Women screenwriters did much better because they did not have to compete with men, and the writing itself was not masculine. Women added a feminine touch to screenwriting. Many women believed these benefits gave them a "golden opportunity" as Holliday points out. This certainly means that women knew they had an opportunity to get paid well, succeed, and make screenwriting a legitimate profession for women. Holiday states that women screenwriters like Frances Marion earned more money than the few men who wrote scripts. ${ }^{10}$ It can be said that women in the film industry could find it easier to support each other since they did not have to

${ }^{10}$ Ibid., 119-120. 
compete with men. Frances Marion may not have been able to get a screenplay sold and succeed in the film industry if men dominated screenwriting. Frances got support from Mary Pickford. As Holliday pointed out, Frances sold her first script to Mary Pickford, which no doubt made her feel accomplished and gave her enough confidence to become one of the most successful and well paid screenwriters in Hollywood history. ${ }^{11}$

Karen Ward Maher in her dissertation titled Women, Filmmaking, and the Gendering of the American Film Industry, 1896-1928 discuses other ways in which women screenwriters were able to enter the film industry. The motion picture industry had functioned like the theater before the late 1910s. The motion picture industry changed during the late 1910 s and early 1920 s. It started to be run like the modern American business, which caused the industry to become male dominated. Men had always been the majority of film directors and producers. Women did manage to gain experience in different types of production work, especially screenwriters. Frances Marion was excited to learn about all the aspects of the movie industry when entering it around 1914. Frances's enthusiasm for the business eventually led her to pursue a career as a scenario writer. Frances Marion became an assistant to Lois Weber in 1914. She did many kinds of work like helping the costume and set designers, and working with Sidney Franklin in the cutting room. ${ }^{12}$ This gave Frances enough experience to start a career in filmmaking. It allowed her to work as an actor, writer, and director. Another scenario writer named Beulah Marie Dix was as an extra, helped out with

\footnotetext{
${ }^{11}$ Ibid., 120.

${ }^{12}$ Karen Ward Mahar, "Women, Filmmaking, and the Gendering of the American Film Industry, 1896-1928," (diss., University of Southern California, December 1995), 351352.
} 
lighting, and also worked in the cutting room. ${ }^{13}$ According to Marion, Lois Weber was a director and Sidney Franklin was another person trying to learn every aspect of the film business. ${ }^{14}$

Maher stated that Pickford had a contract in 1916 that gave her a $\$ 10,000$ a week salary, a $\$ 300,000$ signing bonus, a share of $50 \%$ of the profits, and led her to create the Pickford Film Corporation. The contract made Mary the highest paid star in the film industry and made her a sort of producer who could choose stories, actors, and directors. ${ }^{15}$ Mahar does not examine how she benefited by having a working relationship with Frances Marion. It is clear that Mary saw that Frances Marion was enthusiastic about the film industry and would be a hard worker. This made Mary willing to work with Frances. Mary and Frances worked well together not only because they were hard workers, but also since they were career oriented and could fight their way through an industry dominated by men.

Marion having had experience with several aspects of film work was ready to tackle other jobs in addition to screenwriting by the 1930s. Lizzie Francke pointed out in her book Script Girls-Women Screenwriters In Hollywood that Marion wanted to either direct or produce to gain more control over her scripts. Frances stated that a writer could only maintain any control over their work by writing and directing. Francke stated that Marion was only willing to continue writing screenplays if she could secure a deal to either direct, produce, or do both. Marion had directed some films during the 1920s such as The Love Light with Pickford. The Love Light was the first film where a woman directed Pickford. This made it

\footnotetext{
${ }^{13}$ Ibid., 352.

${ }^{14}$ Frances Marion, Off With Their Heads! A Serio-Comic Tale of Hollywood (New York, The Macmillan Company, 1972), 11, 13.

${ }^{15}$ Ibid., 289-290.
} 
difficult for Frances to direct Pickford. Nevertheless, Frances was still interested and ambitious enough to direct by the 1930s. The problem is that Frances's professional and personal friendship with Mary Pickford failed to give her the opportunity to build a career as a director or producer. Francke stated that although Frances was powerful, she was not powerful enough to persuade producers to give her creative and financial control over her work. Frances tried to secure a directing job by discussing her ideas with Harry Cohn who was the head of Columbia. Cohn did not give Frances the right to direct a picture, but he gave her a contract to produce. Frances Marion's was to produce an expensive western. Columbia was suffering from financial problems because their epic picture titled Lost Horizon was a box office failure. Columbia decided to shelve Frances Marion's western because they felt it would further their financial troubles and possibly cause the company to go bankrupt. Frances wanted to do a film with Gloria Swanson, which also was plagued with problems and failed to develop. Lizzie Francke points out that Frances was disillusioned with the film industry because it was not allowing her to have creative control, and because others had interfered with her attempts to become a director and a producer. Francke states that Frances Marion pursued a career as a fiction writer and a sculpture. Frances knew she would have creative freedom by writing fiction and making sculptures. ${ }^{16}$

Lizzie Francke implied that Mary Pickford had a hard time being directed by Frances Marion on The Love Light because the screenwriter was a woman. A woman had never directed Mary before she did The Love Light with Frances, so she would be very familiar with how men directed motion pictures or their

\footnotetext{
${ }^{16}$ Lizzie Francke, Script Girls-Women Screenwriters In Hollywood, 41.
} 
filmmaking methods. It is not clear what problems Pickford and Frances Marion had while working together on The Love Light. Frances would have had more feminine methods of directing. It is unclear how her feminine ways of directing were challenging for Mary Pickford. Eileen Whitfield points out in Pickford: The Woman Who Made Hollywood that The Love Light failed at the box office because it dealt with World War I. It became unpopular to make films about the war by 1921 when The Love Light was released. The picture also failed because the public did not accept Mary in a dramatic role. Whitfield does not believe that the failure of The Love Light was caused by relationship problems that Frances and Mary might have gone through when making the picture. Mary Pickford did not appear to be happy that Frances had cast her husband Fred Thomson as the spy. Mary stated that Frances "was very much ambitious for Fred, and very much in love with him-and I think that explains everything." This implies that The Love Light failed because Frances let her personal life interfere with the making of the picture and was too focused on her husband to pay close attention to Mary's character and performance. Whitfield does not think that Frances having cast her husband as the spy explains why the film failed. She argues that The Love Light is "rushed and undeveloped." Whitfield also states that Mary's dramatic work in the film is less distinctive than her comedy roles. Whether or not Frances was too focused on her husband to fully develop Mary's character and other aspects of the film is uncertain. Eileen Whitfield is arguing that The Love Light did not fail because of some weakness in the working relationship between Mary and Frances. It was not a success because its subject and Mary's experiment with 
drama did not appeal to the general public. ${ }^{17}$ Perhaps there is a reason why some historians have not delved into the professional relationship of Mary and Frances. Maybe their relationship did not always have an affect on their careers, artistic abilities, and films. Historians have shown that there are things, which shaped and affected Mary's career that had nothing to do with Frances Marion.

Marjorie Rosen Coward argued in her book Popcorn Venus-Women, Movies \& the American Dream that what Alexander Walker called the "idolizing of prepubertal girlhood" had the greatest affect on Pickford's career. Coward believes that it made Pickford and her films successful. The popular attitude towards little girls during the Victorian period was that they were innocent, pure, and sweet. Society continued to have this attitude about young girls when Mary Pickford worked in Hollywood. Marjorie Coward argues that Mary became popular with the general public and achieved fame because she played little girls who symbolized "angelic sweetness" and the innocence of childhood. For Coward, Mary did more than just play angelic girls. Mary achieved success by representing the image of childlike innocence and purity. Mary's angelic image led her to earn $\$ 275$ a week by 1911 and $\$ 500$ a week by 1912 . This was before she worked with Frances Marion. ${ }^{18}$ Even though Frances would later write characters for Mary that were innocent and pure little girls, one can say that she only helped Pickford sustain her angelic image. Coward is arguing, however, that Mary made a bigger and more significant impact on her own career by possessing an angelic childlike image.

\footnotetext{
${ }^{17}$ Eileen Whitfield, Pickford: The Woman Who Made Hollywood (The University Press of Kentucky, 1997), 215.

${ }^{18}$ Marjorie Rosen Coward, Popcorn Venus-Women, Movies \& the American Dream (New York, McCann \& Geoghegan, 1973), 29, 37.
} 
Ally Acker in Reel Women: Pioneers of the Cinema 1896 to the Present also does not look at how other people in the film industry affected Mary Pickford's career. She therefore does not examine Mary's relationship with Frances Marion. Like Marjorie Coward, Acker sees Mary as the one who shaped her own career. She would most likely argue that other film professionals, including Frances Marion, did not help to build and strengthen Mary Pickford's career. Ally Acker would disagree with Marjorie Coward as to how Pickford made a huge impact on her own career. Marjorie Coward would argue that Mary's image of purity made her successful. Ally Acker argues, however, that although Mary's screen image was angelic, there was nothing pure and innocent about the real Mary Pickford. Mary was successful not for having an angelic image. She achieved fame by being shrewd and controlling every portion of her business and career with an iron fist, including her angelic image. Acker does state that Mary knew that her little girl roles had built and maintained her career, and that the public wanted her to play these pure characters. The public liked her playing tragic and naive little orphans with compassion towards an unkind world. Acker illustrates, however, that Mary Pickford did not actually achieve success because she was pure or embodied childlike innocence. Mary Pickford was successful and powerful because she capitalized on her fake angelic image, which made her the first actor in history to become a millionaire. She flourished not for having an angelic image, but for being a strong and smart businesswoman. ${ }^{19}$

Gaylyn Studlar argues in her article called Oh, "Doll Divine": Mary Pickford, Masquerade, and the Pedophilic Gaze that Mary was popular and

\footnotetext{
${ }^{19}$ Ally Acker, Reel Women: Pioneers of the Cinema 1896 to the Present (New York, Continuum, 1991), 53-54.
} 
successful because the general public felt close or attached to her child roles. The public viewed Mary as a child, whether or not she played one. There was a contradictory side to Mary Pickford in which she played both children and adults during the 1910s and 1920s when she was in her 20s and 30s. Mary played children in such films as Daddy Long Legs, Pollyanna, and Through the Back Door. She also played some mature roles to depart from her child characters like in The Love Light where her character grows up when falling in love with a German spy. Mary played both a mature role and a child in Little Lord Fauntleroy, which was released the same year as The Love Light. In Little Lord Fauntleroy, Mary played the mother and her curly haired son. Her mature roles such as in The Love Light and Little Lord Fauntleroy did not stop the public from seeing Mary Pickford as a child. The public felt so close to Mary's child roles that they saw her youthful characters as their friends. ${ }^{20}$ Gaylyn Studlar's evidence comes from a letter that was written to Mary by one of her fans in 1925.

\section{My Dear Little Mary:}

The idea that you are 'just a little girl' is so firmly established in my mind that any attempt to discard it is resented. ... Only a great actress or one who is really a child at heart, could make those little characters so natural that they become our friends, and we refuse to give them up when another 'Mary Pickford' appears in the role of an older girl. We love Dorothy Vernon, too, but we never, never associate her with our own little Mary, Rebecca, and Pollyanna. ${ }^{21}$

\footnotetext{
${ }^{20}$ Gaylyn Studlar, "Oh, "Doll Devine": Mary Pickford, Masquerade, and the Pedophilic Gaze," Camera Obscura 16.3 (2001): 201-202.

${ }^{21}$ Ibid., 204.
} 
Sean P. Holmes argues in The Hollywood Star System and the Regulation of Actor's Labor, 1916-1934 that Mary Pickford protected her rights as an actress by challenging a system that had given producers power. Holmes shows that this helped to make Mary Pickford successful. A "Central Producer" system started in Hollywood by the middle 1910s. This system gave general managers or producers complete control over the studio. The producers managed the planning and budgeting of films, and also organized numerous departments involved with production. They could control the income of actors. Holmes shows that producers by the 1920s and 1930s did not entirely control how much actors earned for their films. A small number of actors by the late 1910s including Mary Pickford were well paid for their hard work. By 1916, Mary Pickford was receiving \$10,000 a week from Famous Players-Lasky and 50\% of the profits on the films she made for them. When Pickford moved to First National in 1918, her salary for three films was $\$ 675,000$. She continued to receive $50 \%$ of the profits when working for First National. This led her to have an income of \$1 million dollars a year. Pickford received a large enough income yearly to make it impossible for producers to control how much money she made yearly. Mary Pickford became a successful businesswoman since her income was large. She was able to make percentage deals that were unusually profitable. These deals increased her income and made her wealthy. ${ }^{22}$

It is frustrating that historians have paid little attention to the relationship between Pickford and Marion. A series of letters do reveal that the two women

\footnotetext{
${ }^{22}$ Sean P. Holmes, "The Hollywood Star System and the Regulation of Actors' Labour, 1916-1934," Film History 12, no. 1 (2000): 98, 105, 112.
} 
had been very close. We can conclude from the letters that their relationship did help them survive not only the film industry, but also life.

\section{Chapter 2: The Letters}

Mary Pickford sent Frances Marion an Easter plant with a card in 1965. The card read:

"Frances Marion Thomson "From Squeebie Skunk Face of Squatville."

Frances Marion responded to the plant and card with a letter. The letter was probably written on April 18, 1965. Frances Marion's letter shows that she and Mary Pickford had built a profoundly strong friendship. It illustrates that their friendship was strong because they survived life together. It is safe to assume that this includes their professional and personal lives.

Squeebie darling: As I gaze at the beautiful flower greeting from you I'm aware of the wondrous realization that we have arrived at our golden anniversary of friendship. Half a century of love, understanding and companionship. We've shared our joys and sorrows. We've known success together. We've faced temporary set-backs with our chins up. And we have never grown old-in spirit. Nature may give us an occasional swat in the tail, break a few ribs, dim a pair of eyes, slow down what once were dancing footsteps, but she can't age the heart and the brain. Not on our side of the ledger! We'll go on creating, organizing, and fulfilling our destiny until Gabriel toots his horn. And when he does, I'll be mad as hops, because I love this business of living in spite of inexorable odds which pop up from time to time. I see you so clearly with my inner eyes... I see the little girl, you rolling your hair on curlers... I see the burgeoning woman with her first great love... I see you straightening your shoulders to bear cross after cross when death took toll of your loved ones... I see the gallant fighter you, challenging hypocrisy and what you believe to be false and unsound... then I also see, as the years roll along, the rewarding love between you and Buddy through out the disappointments and heartaches that come to all of us. Yours is a magnificent life, Mary, and should be written, not by ordinary scribe, but by a top historian. Your personality and achievement are an integral part of America and belong to the ages. 
I love you very much, Frances. $^{23}$

Mary Pickford responded to Francis Marion's letter on May 12, 1965.

I am sure "Solomon in all his glory" was not more appropriately adorned for Easter than the Azalea plant you sent with its fascinating Easter eggs and quaint oriental parasols protruding above the blossoms. The plant is still in full bloom and will eventually end up in the garden where it will remind me of the golden anniversary of our friendship, so beautifully expressed in your Easter letter. Your humorous acceptance of the passage of time and your indomitable determination to live it constructively and fully "until Gabriel toots his horn" is an inspiration and one of the many reasons why you are so dearly loved by everyone. ${ }^{24}$

Frances Marion sent Mary Pickford and her husband Buddy Rogers a letter

on January 5, 1967. Here is a portion of that letter in which Frances Marion

explains the reason for their survival.

Dear Mary and Buddy:

Peace. It sounds like a cry of despair in the world today. I guess we are lucky to have lived in what is now called "the golden age," before wars. Yet there's still so much beauty around us that in spite of our reoccurring problems we find the joy of living strongly anchored in our hearts. I wrote in a story in my early twenties, "Life is a series of little green islands in a sea of tears.",25

Frances Marion discussed in a portion of a letter she wrote to Mary Pickford

on January 28, 1968 why Pickford was a success in the film industry and had a good life.

I relived your never-ending years of hard work when you fought so fairly, so courageously against odds that would have defeated an average person. But you were not born to be an "average person," you were destined to be a leader, to carry high the framers of success, to have achieved enduring

${ }^{23}$ Francis Marion to Mary Pickford, 1965, Mary Pickford Collection, Department of Special Collections, Margaret Herrick Library, Academy of Motion Picture Arts and Sciences, Beverly Hills.

${ }^{24}$ Mary Pickford to Francis Marion, May 12, 1965. Mary Pickford Collection. Department of Special Collections, Margaret Herrick Library, Academy of Motion Picture Arts and Sciences, Beverly Hills.

${ }^{25}$ Frances Marion to Mary Pickford and Buddy Rogers, January 5, 1967, Mary Pickford Collection, Department of Special Collections, Margaret Herrick Library, Academy of Motion Picture Arts and Sciences, Beverly Hills. 
triumphs. A little golden haired girl who became a giant among great artiststhat's my Squeebie! My site has not been impaired. I see you as I first gazed upon you over half a century ago. Though even then my eyes were somewhat dimmed by tears at your charm. Then, as the years rolled along, so swiftly, often too swiftly, I remember how valiantly you walked through those deeply-shadowed canyons of grief, always holding your head high and never unimposing your heartaches on others, but bearing your suffering in silence. Few have been given such strength. Mary, and that's why you have been blessed among women, and given the assurance of Buddy's devotion through out these autumnal years. ${ }^{26}$

Mary Pickford and Frances Marion did not always have an opportunity to speak to one another in their later years. There are two letters that illustrate that they felt a need for one another whenever they had difficulty trying to stay in contact. The first letter dated December 17, 1969 is by Frances Marion to Mary Pickford.

Squeebie dear-

Don't be a little stinkpot, but when I call again talk to me. Both of us can do with some loving laughter and you might remember I'm now churning on my eighties and that the thread of my life is rapidly fraying. This is a sneaky reminder that I don't want to miss that last drop of honey before my final exit, and you were always to me the very essence of honey. Bless you, Miss Squatrock. Frances-December 17, $1969^{27}$

The second letter dated September 11, 1964 is by Mary Pickford to Frances Marion.

Dear Frances,

I was so sorry not to be able to talk with you when you called on August $18^{\text {th }}$ but, as Miss Helm explained to you, we were knee deep in the excitement of house guests: Gwynne and Bud Ornstein, and their children, Mary and John, plus friends from Spain. I tried to reach you on August $26^{\text {th }}$ and again several

${ }^{26}$ Frances Marion to Mary Pickford, January 28, 1968, Mary Pickford Collection, Department of Special Collections, Margaret Herrick Library, Academy of Motion Picture Arts and Sciences, Beverly Hills.

${ }^{27}$ Frances Marion to Mary Pickford, December 17, 1969, Mary Pickford Collection, Department of Special Collections, Margaret Herrick Library, Academy of Motion Picture Arts and Sciences, Beverly Hills. 
times this week and Miss Helm has reported "no answer" so I presume you are away on a vacation. Buddy and I are getting ready to go to the Orient around the middle of this month. If we do not complete this call before our departure, I shall look forward to seeing you soon after our return. In the meantime, Buddy joins me in sending our love.

Affectionately. September 11, $1964 .^{28}$

There are letters written by other people who were friends with Frances Marion, Mary Pickford, and Mary's husband Buddy Rogers. These letters were meant to keep Mary Pickford and Frances Marion informed about each other's well being. More importantly, they serve to keep Frances Marion and Mary Pickford close. The authors of these letters are unknown. The first letter was sent to Buddy Rogers.

Mr. Rogers, Friday-May 5, 1972, 9:30a.m.

I had a call from Frances Marion. She is now back at her hotel with a nurse in constant attendance. She says the doctors told her that she has some form of St. Vitus Dance, which may take her at any time. She is reconciled and ready to go. Sends love to you and Mrs. Rogers. Later when I gave Mrs. Rogers the above message she had me order $\$ 15$ floral arrangement sent to Frances Marion with card "All my love to you, Frances dear, From Squeebie Skunk Face of Squatville. ${ }^{29}$

The second letter addressed to Frances Marion is particularly important. It shows how Mary Pickford felt about Frances Marion as a professional companion.

Dear Frances, May 16, 1972

So glad that you and Mary had such a nice long telephone visit yesterday. Your beautiful roses and note with them arrived on Mother's Day, all of which reminded her of the many happy years you shared. Mary said in discussing it with Miss Helm, "Frances Marion was the pillar of my career,"

\footnotetext{
${ }^{28}$ Mary Pickford to Frances Marion, September 11, 1964, Mary Pickford Collection, Department of Special Collections, Margaret Herrick Library, Academy of Motion Picture Arts and Sciences, Beverly Hills.

${ }^{29}$ Unknown author to Mr. Rogers, May 5, 1972, Mary Pickford Collection, Department of Special Collections, Margaret Herrick Library, Academy of Motion Picture Arts and Sciences, Beverly Hills.
} 
and then she asked Miss Helm to get you on the telephone. I understand that it was a colorful and animated conversation and Miss Helm says that she told you twice that she would come to see you. This is not possible for our Mary as she is not strong enough to even go downstairs, so I would like to make a suggestion that I came to get you to Pickfair as I understand you are able to move about and have the strength. This, of course, would be contingent on one of Mary's good days, which come and go and are unpredictable, but I am sure you understand. I hope we can work out something as I know it would be a happy time for both of you and brighten all for Pickfair.

With Love. ${ }^{30}$

Frances Marion was to receive a lifetime membership in the Writer's Guild of America at a screening of her film, Stella Dallas in 1972. There are two letters that concern the occasion. The second one further demonstrates that Frances Marion was important to Mary Pickford. It shows that some of the best times in Mary Pickford's life were those she spent with Frances Marion.

Dear Mrs. Rogers,

Miss Marion has promised to attend the showing of her film Stella Dallas, and following the screening, she will be presented with a lifetime membership in the Writer's Guild and with greetings from her friends and associates over the years. I feel sure that Miss Marion would be very happy and very honored to hear from you on that evening. Miss Marion seems happy and vigorous, and it will be a genuine pleasure for us to try and make this evening a milestone occasion for her.

David Shepard-November 13, $1972^{31}$

Dear Frances,

It is a source of great regret to me that I am unable to join you this evening for the well deserved tribute the Writer's Guild of America and the Los Angeles County Museum of Art are bestowing upon you. I can think of no one more worthy of this honor. Your natural talent for writing, acting and directing contributed so much to the growth of the infant film industry which

${ }^{30}$ Unknown author to Frances Marion, May 16, 1972, Mary Pickford Collection, Department of Special Collections, Margaret Herrick Library, Academy of Motion Picture Arts and Sciences, Beverly Hills.

${ }^{31}$ David Shepard to Mary Pickford, November 13, 1972, Mary Pickford Collection, Department of Special Collections, Margaret Herrick Library, Academy of Motion Picture Arts and Sciences, Beverly Hills. 
has blossomed way beyond our greatest expectations, and you are still giving of yourself in the worthwhile pursuit of painting and writing. I not only enjoyed working with you, but I am most grateful for your friendship, which has given me some of my most cherished memories throughout the many years.

Miss Pickford, November 24, $1972^{32}$

Frances Marion's autobiography titled Off With Their Heads was published in 1972. Her book received support and it became clear that she should be honored for having made great contributions to the film industry. Although the year of the first letter to Buddy Rogers was not on the letter, it is safe to assume that it was written in 1972.

Dear Buddy: Tuesday, October 10,

Here is the brief review of Frances Marion's book, which we promised to send to you. Wish it could have been longer; but space is never long enough, when you write about someone you care about. We understand that Frances publishers were very happy about the review and will be quoting it in ads. Incidentally, I've also written an article about Frances, for the Chicago-Sin Times. We'll send you a clipping when it appears.

All our love to Mary...Fondly, Bob and Irene ${ }^{33}$

Dear Mr. Andrews: December 7, 1972

Thank you for your letter of November $28^{\text {th }}$. It and your article from the Chicago Sun-Times about Miss Marion will be put in the record and presented to the Board of Governors when they vote honorary awards. Incidentally, I can't think of no better presentation about Frances Marion than your article. It is warm and beautifully written.

Daniel Taradash ${ }^{34}$

${ }^{32}$ Mary Pickford to Frances Marion, November 24, 1972, Mary Pickford Collection, Department of Special Collections, Margaret Herrick Library, Academy of Motion Picture Arts and Sciences, Beverly Hills.

${ }^{33}$ Bob and Irene Andrews to Buddy Rogers, October 10, Mary Pickford Collection, Department of Special Collections, Margaret Herrick Library, Academy of Motion Picture Arts and Sciences, Beverly Hills.

${ }^{34}$ Daniel Taradash to Mr. Andrews, December 7, 1972, Mary Pickford Collection, Department of Special Collections, Margaret Herrick Library, Academy of Motion Picture Arts and Sciences, Beverly Hills. 
Dear Miss Helm: January 19, 1973

Mrs. Andrews thought that Miss Pickford might like to see the letter copy I enclosed. There's no way to guess whether the Academy governors will vote "yes" on an honorary award to Frances Marion, but certainly, she has earned it far more than some who may receive it. I wrote a review of her new book, "Off With Their Heads," for the Chicago-Sun Times for which I write quite regularly and followed it with an interview with Frances, which the SunTimes featured. She knows about this, but doesn't know both went to the Academy. Miss Pickford may have noted that our Writer's Guild recently made Frances Marion an honorary life member. When I last talked with her on the phone, she seemed very well and as gallant and gay as ever. Please give our love to Miss Pickford; and Irene's thanks for inviting her to go to the Arthritis luncheon.

Bob Andrews ${ }^{35}$

Mary Pickford and her husband Buddy Rogers liked Frances Marion's book Off With Their Heads very much. A letter was written to Frances Marion in September 1972 about how Mary and Buddy enjoyed her book. The author of the letter is unknown. It is safe to assume that Mary Pickford never saw it or knew it was written. It is noted on the letter that Buddy Rogers signed it, but said that it should not be shown to Mary. The reason for why Buddy did not want Mary to see the letter in not known.

Dear Frances, September 20, 1972

Mary was so pleased to receive your book, "Off With Their Heads," which you so lovingly autographed to "Squeebie." They both enjoyed every page; Mary was grateful to you for having given so much space to describing her career. $^{36}$

A letter was written to Frances Marion in April 1973. There is no author listed, but it seems evident that Mary Pickford wrote it. The reason why the letter

${ }^{35}$ Bob Andrews to Miss Helm, January 19, 1973, Mary Pickford Collection, Department of Special Collections, Margaret Herrick Library, Academy of Motion Picture Arts and Sciences, Beverly Hills.

${ }^{36}$ Unknown author to Frances Marion, September 20, 1972, Mary Pickford Collection, Department of Special Collections, Margaret Herrick Library, Academy of Motion Picture Arts and Sciences, Beverly Hills. 
is more than likely written by Mary Pickford is because it can accurately describe the relationship she had with Frances Marion near the end of their lives.

Dear Frances, April 24, 1973,

Thank you for the beautiful "sweetheart" roses which arrived for Easter. They brighten my room, but much more than that, they cause me to lovingly meditate on the past joys and sorrows that we have shared. Let us keep this invisible thread of friendship between us always, warming our hearts and stimulating our thoughts. ${ }^{37}$

Frances needed Mary for comfort when her health was deteriorating. Harry Finley wrote Mary Pickford a letter concerning Frances poor health. The date of the letter is unknown, but it was obviously written sometime between 1972 and early 1973.

Harry Finley to Mrs. Rogers,

Francis Marion is going down fast. It would mean much to her to be with her for a few minutes. Marion has lost control of her hands; they wander and jerk most of the time. ${ }^{38}$

Mary Pickford's letter to Frances Marion on November 24, 1972 is important. Mary stated in the letter that Frances had a natural talent for writing. ${ }^{39}$ Frances talent for writing did make her a successful filmmaker. It also helped to build, innovate, and strengthen the film industry and movie making. Equally significant, it allowed her to develop a healthy relationship with Mary Pickford. It is clear from the letters that the two women had a great history together. It is further evident in some of the letters that their friendship helped them cope with

${ }^{37}$ To Frances Marion, April, 24, 1973, Mary Pickford Collection, Department of Special Collections, Margaret Herrick Library, Academy of Motion Picture Arts and Sciences, Beverly Hills.

${ }^{38}$ Harry Finley to Mrs. Rogers, Mary Pickford Collection, Department of Special Collections, Margaret Herrick Library, Academy of Motion Picture Arts and Sciences, Beverly Hills.

${ }^{39}$ Mary Pickford to Frances Marion, November 24, 1972, Special Collections, Margaret Herrick Library, Beverly Hills. 
the difficulties of life and made their happiest times even more enjoyable. Frances made this clear in her Easter letter to Mary in 1965. Frances stated in the letter that she and Mary had together experienced "joys, success, temporary set-backs, and sorrows." ${ }^{40}$ Mary Pickford wrote to Frances Marion on November 24, 1972 that she had enjoyed working with her. Pickford also stated that Frances's talent for filmmaking helped the film industry grow. ${ }^{41}$ This shows that Mary admired and respected Frances for her talent and dedication to the movie industry, which is most likely a reason for why Mary became friends with Frances. It is essential to try and understand how this relationship became strong and why it lasted until Frances Marion died in 1973.

\section{Chapter 3: The Films}

Frances Marion was a talented screenwriter and very knowledgeable about writing for the cinema. Her talent as a screenwriter led her to achieve success in the film industry, but also allowed her to have a working relationship with Pickford. Her book titled How To Write and Sell Film Stories makes it evident that she was skillful as a screenwriter and knowledgeable about the business of Hollywood.

\footnotetext{
${ }^{40}$ Frances Marion to Mary Pickford, 1965, Special Collections, Margaret Herrick Library, Beverly Hills.

${ }^{41}$ Mary to Frances, November 24, 1972, Special Collections, Margaret Herrick Library, Beverly Hills.
} 
Marion's How To Write and Sell Film Stories is important to examine. She discusses what she learned about being a screenwriter in Hollywood. It could function as a lesson on screenwriting and the business of Hollywood for anyone wanting to become a screenwriter. The only problem is that the film business and its rules have most likely changed since How To Write and Sell Film Stories was published in 1937. The stories Marion wrote are dated today as is evident from Rebecca of Sunnybrook Farm, Amarilly of Clothes-Line Alley, and The Love Light. How To Write and Sell Film Stories does give us an understanding of who Marion was as a screenwriter and a businesswoman. Marion's book is useful because it may give us an idea about her professional relationship with Pickford. It could be stated that Marion's knowledge about screenwriting strengthened their relationship and made it last.

Marion argues in How To Write and Sell Film Stories that a good film writer has to first understand life, and then make their readers and viewers feel. She states that the commercial film writer would waste their time writing about things that are "too sensational or bizarre." The screenwriter should not put their characters in situations that are far more thrilling and strange than people experience. If the writer puts their characters into sensational situations, than their readers and viewers cannot get a clear picture of real human emotions and the actual experience of living. The film writer needs to be honest about how people live. They must show the way people emotionally respond towards life. Marion asserts that the film writer needs to tell their readers and viewers about the lessons of life. They can do this by clarifying the most important human qualities. They must be familiar with human behavior because it reveals those essential 
characteristics. The writer has to examine human feelings and how people have emotionally reacted towards life. They have to become aware of the emotions that people commonly experience, and write about those feelings. ${ }^{42}$

Marion discuses ways that film writer's can understand life and emotionally affect their readers and viewers. She states that a writer can gain knowledge about life by observing people. This helps the writer to understand their "motives and acts." The film writer needs to make contact with various aspects of American life so they can learn about human beings and the world. A film writer can only create a believable screenplay if they are knowledgeable about people and life. They must learn to identify people's most interesting qualities, and what types of situations these traits lead them into. ${ }^{43}$

Marion states that when a screenwriter has created a plot and characters and integrated them into a story, their screenplay could become financially valuable. A beginning screenwriter may have an excellent opportunity to get their screenplays made into films in several ways. They could get an established agent who is favored by studio executives. This might make it likely that studio executives will read their screenplays. It also helps for a beginning screenwriter to get a job at a studio, so that they become known and hopefully trusted by studio executives. Once the screenwriter has gained the trust of others in the industry, they will be able to present their stories to the story editor. Marion strongly advised professional and amateur screenwriters to carefully read their stories so that they will not sell the rights unintentionally. It is best for screenwriters to sell

\footnotetext{
${ }^{42}$ Frances Marion, How To Write and Sell Film Stories (New York, Garland Publishing, Inc., 1937), 122, 152, 154-155.

${ }^{43}$ Ibid., 168-169, 170,
} 
their stories to the studios by first having them published in magazine form. ${ }^{44}$ One can conclude from Marion's How To Write and Sell Film Stories that a film writer may get their story made into a movie if they gradually get themselves known to the studios, know how to protect their work, and write screenplays that can affect people emotionally.

The movies that Marion wrote for Pickford reveal what she learned about life. More significantly, these films represent attitudes about life and human nature that one can say Marion and Pickford shared. They help us understand their relationship and why it was strong. Among the most important films that they made together are Rebecca of Sunnybrook Farm, Amarilly of Clothes-Line Alley, and The Love Light.

The most interesting aspects about Rebecca of Sunnybrook Farm, Amarilly of Clothes-Line Alley, and The Love Light is that they show the primary job women had in Hollywood was to teach morality so that society could be held together. Marion and Pickford had a duty as women to keep society integrated by giving the general public moral lessons. It can be stated that Marion and Pickford created these films to fulfill this job. The purpose of the films is to give audiences lessons on how to have meaningful lives. The message in Rebecca of Sunnybrook Farm is that people can live peacefully and happily by helping one another. Amarilly of Clothes-Line Alley shows that people can find happiness by not looking towards wealth for contentment. Although the main characters in Rebecca and Amarilly

${ }^{44}$ Ibid., 187, 192, 197, 199. 
are women, their messages can be useful for men too. The Love Light is more complex and its message is aimed primarily at women. The film states that a woman's job is to keep society, especially their families, intact; this includes raising children. There are times when it is difficult for women to hold society together, but they must fight for their right to do so to attain happiness.

If it is accurate to say that women in Hollywood had to hold the public together by giving them moral lessons, than we can draw a possible conclusion as to why this may be the case. Perhaps women were seen by society as being pure. Even though the lessons and messages in Rebecca and Amarilly could benefit men, Pickford and Marion made these films. It can therefore be stated that women were expected to show their purity through film by teaching the public wholesome lessons about caring for other people, doing away with greed, and basically being good. Marion and Pickford show in The Love Light that women must care for other people by struggling to keep their families and society together.

Pickford performed in Rebecca of Sunnybrook Farm, which was released in 1917. Marion adapted the screenplay from the book by Kate Douglas Wiggins. The film's moral message is not new, but it represents an idea that has appealed to many people. The message of Rebecca of Sunnybrook Farm is that people can become good and improve the quality of their lives by helping others. Pickford plays a little girl named Rebecca Randall who comes from Sunnybrook Farm. Rebecca cannot be raised properly on the farm because it is in a mortgage crisis. She leaves Sunnybrook Farm to live with two wealthy aunts named Jane and Miranda, who can give her a better upbringing. Miranda is described in the film as 
having a "heart which she uses for no other purpose than the pumping and circulating of blood." This means she will be strict towards her niece. Rebecca Randall is a troublesome child, which makes Miranda stringent with her. Rebecca sees herself as being more special and deserving than other people. She thinks about herself and her own needs rather than being considerate towards others.

Miranda and Jane serve pie one evening, but Rebecca demands a bigger piece than she is given by saying, "Gee! What a little bit!" This angers Aunt Miranda, who gives the piece of pie to Jane and forbids Rebecca from eating one. Rebecca is sent to the kitchen to put the pie away, and still desires a piece. She sees a sign that reads, "God helps those who help themselves," but misinterprets it. She mistakenly believes the sign means that God will help her for stealing a piece of pie and taking everything else she wants in life. This only strengthens her belief that she is special and important enough to get whatever she desires. Although another sign in the kitchen reads, "Thou Shalt Not Steal," Rebecca chooses to ignore it and its meaning. Rebecca decides that God has given her a right to take a piece of pie and eat it. She steals a piece of pie without knowing it is wrong.

Rebecca Randall eventually joins the local circus, and performs a stunt in which she dangles from a rope while riding a horse in circles. Rebecca feels that if she helps herself, than she will find things in life that are pleasurable and exciting. She feels lucky, fortunate, and special to be doing the stunt. Rebecca is also thinking that the stunt will give her a thrill and that the audience will see her as exceptional for performing it. Rebecca does not realize that the stunt is dangerous and could lead to an accident, which may cause injury to both herself and 
members of the audience. The stunt does go terribly wrong. Rebecca is unable to stay on the horse, and dangles from the rope in mid air while swinging in circles. The audience runs for safety because they fear that Rebecca will crash into them. Aunt Miranda manages to get Rebecca down and spanks her for not considering the safety of others, and even her own.

Rebecca decides she can no longer live with her aunts. She writes her aunts a letter stating she cannot "dwell" with them again. Aunt Jane reads the letter and is horrified. Rebecca tries to run away from her aunts during a violent storm. She is nearly killed when being struck in the head by flying timber. Rebecca is saved by one of the young townsmen. He brings Rebecca into his home and gets a doctor to care for her. Rebecca realizes that other people care about her well being, which makes her feel pleasantly shocked and very touched. This experience teaches her to care about other people and their well being more than herself. Rebecca starts to show concern for the Simpson family. Mr. Simpson is too poor to buy his wife a wedding ring. Wedding rings are fashionable in Riverboro, where Rebecca resides with her aunts. Riverboro is also where the Simpsons live. Rebecca feels that the residents of Riverboro are "set against poor Mrs. Simpson cause she doesn't wear any jewelry." Rebecca says, “oh, dear, if they would only give them away as soap premiums." Rebecca received a ring from a guy who said it belonged to his mother. She decides to give it to Mr. Simpson to make his wife happy. Rebecca says to Mr. Simpson, "when you put it on her finger Mr. Simpson, all the ladies in Riverboro will speak to her again.” Mr. Simpson replies 
by saying, "I'm dreadfully ashamed I ain't never done it before." Mr. Simpson gives his wife the ring and both become happy. ${ }^{45}$

Marion and Pickford made Amarilly of Clothes-Line Alley, which was released in 1918. Marion wrote the script and Pickford played Amarilly Jenkins. The film criticizes the upper class and the idea that wealth gives people happiness, security, and basically makes their lives better. Its message is that lower class and hard working citizens can still find joy and peace in their lives. It also states that lower and working class people might find things in their lives to appreciate and feel fortunate to have been given. Even if someone is in a lower class, they may be happy. Amarilly Jenkins comes from the poor and working class. Her mother Americus works as a maid, but is not unhappy or ashamed about being poor. The film begins with Americus washing clothes. A sign reads, "honest wash done by Mrs. Americus Jenkins.” The sign means that Americus Jenkins has pride in being a hard working mother even though she is poor. It also means that the work has given her high morals. This has made the Jenkins family honorable.

The poor of course performed the cleaning jobs around town, but the Jenkins family including Amarilly felt cleaning work was noble and they were content to do it. Amarilly started doing cleaning work at the Gordon Willis Studio. She observed the broken china lying all over the floor and said, "what a swell scrap there must a' been around here to bust up all this china!" Amarilly was determined and pleased to clean the mess. She later sees dirt all over the studio and says, "there ain't this much dirt in all Clothes Line Alley." Gordon Willis assured her that it "isn't dirt-it's atmosphere that cost his Aunt ten thousand

\footnotetext{
${ }^{45}$ Marshall Neilan's Rebecca of Sunnybrook Farm.
} 
dollars!" Gordon Willis's aunt Mrs. Phillips is wealthy. He thinks it would be a good idea if his aunt found a place for Amarilly to stay. Gordon says to Amarilly, "kindness is my Aunt's hobby. I'll see if she can't find a place for you." Amarilly protests his suggestion by saying, 'I'd rather stay here an' go on with the scrubbin! Gran'ma scrubbed...Ma scrubs...an' I likes scrubbin'!!”

Gordon calls Mrs. Phillips and says to her, "couldn't you find some unoccupied room in the house for this child?" Mrs. Phillips likes the idea of giving Amarilly a room to occupy. Gordon's aunt is a member of a group called "the Society" that are philanthropists. The Society likes "charity because it reflects glory upon the giver." Mrs. Phillips wants to give Amarilly a room to stay in as an experiment. She says to the Society, "perhaps we can use the little girl my nephew is bringing here, as one of four experiments.” Mrs. Phillips believes that environment makes a woman. Her theory is that a high-class environment will make a poor and unfortunate girl into a woman that is respectable. Her experiment is to change Amarilly into a "social equal." Mrs. Phillips wants to turn Amarilly into the figure of a wealthy woman. Gordon arrives at Mrs. Phillips place with Amarilly. A lady observes Amarilly and says in support of Mrs. Phillips's experiment, "what an interesting specimen! Lets give her every opportunity for mental progression. The experiment will be psychological.” Amarilly is not happy with the lady's comment and says, "another crack like that-an I'll crown her! That dame must o' swallowed the dictionary." Even though Amarilly tried to please Mrs. Phillips, she did not want to live with her and be part of the high-class lifestyle. Amarilly desired to leave the high-class environment and go home to her mother in Clothes Line Alley. She protests the upper class society by saying, "I 
don't want to be a lady-I want to go home." Amarilly at one time says to the butler, "I never knowed what a swell place Clothes Line Alley was, 'til they took me away from there. Guess- "cause it's home."

Mrs. Phillips has a party and invites both her high-class friends and Amarilly's mother Americus. The party causes a clash between the upper and lower class cultures. There is no understanding between the wealthy ladies and Americus. The wealthy guests look at Amarilly's family with curiosity and Mrs. Phillips is not amused when Americus dances. Americus says to one lady named Colette King, 'I don't know enny of youse ever took in washin'-but my-ain't the soap high!" Colette is offended by the comment and says to Mrs. Phillips, "How dare that woman insult me by speaking of my past?" Amarilly says to Mrs. Phillips, "I'm sorry my poor ma hurt the lady's feelings. She didn't mean it“please forgive her... she's just old fashioned." Mrs. Phillips nevertheless says to her wealthy friends, "my dears, this is our reward for trying to raise the unfortunates of the slums to a higher social plane." Colette King says to Gordon, "I am sorry, Gordon that you should be so humiliated." Colette worried that Gordon was feeling disgraced for bringing home a poor girl from Clothes Line Alley, even though Gordon had considered marrying Amarilly. Mrs. Phillips never liked the idea that her nephew would marry Amarilly. She once said to her nephew, "would you disgrace your family name and destroy your social positionby such a marriage?"

Amarilly and her mother go back to their normal and comfortable lives in Clothes Line Alley. Americus Jenkins is seen talking to other lower class ladies from Clothes Line Alley, and she seems perfectly content to be back in the world 
of the working class. Amarilly gets back together with her former boyfriend Terry who she will eventually marry and says to him, "ma's goin' to the Murphy weddin' tonight. Come on over for supper." This shows that the poor working class in Clothes Line Alley was a close and strong community that held itself together. This closeness gave them a sense of morality, and gave them comfort, protection, and happiness. $^{46}$

Marion wrote and directed The Love Light, which was released in 1921. It stars Pickford as Angela Carlotti. The name Angela means angel when translated. Angela lives in a small fishing village, and tries to protect it as if she was its guardian angel. The film makes a point that women are guardian angels and soldiers are meant to protect their communities and families. The film looks at how World War I prevented women from protecting their neighbors and families. It also shows that World War I made it impossible for women to be mothers.

Angela has two brothers named Antonio and Mario. She is very motherly towards Mario because he is her younger brother. The film points out that Mario is the "joy and bane of Angela's existence." Mario annoys Angela like when he steals Father Lorenzo's chicken at the dinner table, which causes her to chase him. Even though Mario can irritate Angela, she loves him dearly. Angela expresses her love to Mario by being protective of him. Angela begins to lose the power to protect her family when her older brother Antonio is sent to fight in the war and dies; this makes her more motherly towards Mario. After Angela realizes that Antonio has been killed, she says to Giovanni, who she is supposed to marry,

${ }^{46}$ Marshall Neilan's Amarilly of Clothes Line Alley. 
"Mario must not go!...... They will kill him too!" She begins to worry more about Mario, and is especially bothered at the thought of her brother not washing himself. Angela notices that Mario is dirty after he claimed to have cleaned himself the previous day, and she calls him a "pig." Angela realizes that Mario will be sent to fight in the war while cleaning him. She says to Mario, "it may be a long time before I'll be digging out your ears again." Angela tries to believe that Mario will return home safely and that she will be able to protect him again. After Mario is sent to fight in the war, Angela looks at a statue of the Virgin Mary and says, "send Mario home without too many wounds." Angela is also praying to the Virgin Mary that Giovanni, who has been sent to war, will come home safely in hopes of building a family she can protect. It is frightening for Angela and any woman to see their loved ones get sent away from home to fight in a war. It is brave of women to care for the home and community while the men in their lives are fighting in a war. Angela takes Giovanni's place as keeper of the lighthouse. The film describes women at a time of war; “women's part in war-no martial music hers, no joys of battle won; but waiting, dreading, -- her frail shoulders bent to carry on man's unfinished tasks; silent, patient toiler-anguish torn, -- who shall say that she is not the bravest soldier of them all?" Even though Angela is brave in trying to deal with the pain of Mario and Giovanni fighting in the war, she loses her power to protect Mario. Angela learns that Mario was aboard a ship that was "bringing wounded soldiers home." She is shattered when a woman tells her that the ship "was sunk by an enemy submarine."

Angela also fails to protect her fishing community. She rescues a man named Joseph who washes up on shore. Joseph claimed to Angela that he was an 
American and a deserter. He said that a storm caused him to desert. Angela believes everything Joseph is alleging. She responds to his claim of being an American by saying, "Never before have I met the breed...it is very nice." Angela hides Joseph in her home and quickly falls in love with him. Angela is in need of love since Giovanni and her brother Mario are fighting in the war. The film states that, "as Joseph lingered, Angela knew that the love which sleeps in every woman's heart, had at last awakened." She decides to tell Father Lorenzo about the man. Lorenzo says to her, "this stranger that you wish to marry in secret. Are you sure, my child, that you love him?" Angela responds to Lorenzo and says, "It must be love, Father Lorenzo. I suffer so much the sweet pain of happiness." Angela unfortunately discovers one evening that Joseph is a German; she becomes horrified when hearing him talk German in his sleep. Angela says to Joseph in shock, “you...a German!” He replies by saying, “Angela, I am an enemy of your country, but not a traitor to you. You can't hate me, Angela, for serving my own country. It is every man's duty." After the townspeople discover that some chocolate is missing, one man named Pietro says, "A thief in this village means a stranger! A stranger is an enemy! Perhaps-a spy!” They figure out that Angela stole the chocolate and confront her about it. She first claimed to them that she stole the chocolate so she could send it to Mario. The truth is that Angela stole it for Joseph and she confesses her crime to the townspeople by saying, "I have lied to you! Betrayed you! I have been hiding and protecting an enemy of our country... a spy!" Joseph comes out of his hiding place and reveals himself to the townspeople. Angela blames Joseph for Mario's death after she learns he was killed. While Angela and Joseph were in love, she used the 
lighthouse to send him love signals. Angela says to Joseph with disgust, "you used my love signals to send him to his death!" This means he used the lighthouse's signals to make the boat Mario was aboard to go off course and crash. Pietro pulls out a gun to shoot Joseph. The German spy tries to escape and after struggling physically with some townspeople, he jumps off a cliff to his death. Angela had not only been unable to protect her neighbors from a potential threat, but she failed to hold her town together and her actions created chaos. Angela eventually has a baby girl named Dolora. Angela had suffered from "successive shocks of sorrow," but raising a child for months helps her mind sleep and gives her peace. The war unfortunately deprives Angela from her right to be a mother. It is another reason for how Angela became an "innocent victim of a far off conflict."

A woman called Maria suffers from two tragedies as a result of the war; both her husband and little son have died. The film states that Maria has been "caught in the swirl of war's hysteria, driven to distraction by loss of husband and child." Maria "conceives a cruel scheme" to overcome the pain of losing her husband and child. She steals Dolora from Angela, and tries to justify this kidnapping by telling a nun that Angela is insane and cannot raise the child. Angela finds her baby missing and becomes distraught. Sister Lucia misinterprets Angela's distressed behavior as craziness. The nun is "convinced that Angela is unfit to care for the child." Maria is allowed by the nuns to raise the baby girl. Angela is among the "innocent and helpless" that have been crucified by the war. She longed for the baby and would hold a piece of the child's clothing to feel comfort. Angela goes to the convent one day because she believes that is where her child is 
harbored. She goes to the convent and finds Maria and the baby. She realizes the child is Dolora, but says to Maria, "I had a little baby-a-little girl!" Angela starts to feel pain in her heart when the child reached for her, but she walks away from Maria and the baby feeling lost without a child.

Giovanni returns from the war, but had lost his eyesight in battle. Angela says to him, "I saw my own baby-and I didn't know her." Maria realizes that Angela recognized the child and will try and get her back. She wants to prevent Angela from getting the baby by sailing away to Genoa with the child and one of the villagers named Tony. Maria and Tony's boat crashes into rocks as a result of a storm and the failure of the light from the lighthouse to guide it. Maria dies in the crash, but Angela manages to save her baby. Angela and Giovanni get married, move into his home, and are now able to raise the child. ${ }^{47}$

How can the relationship between Marion and Pickford be understood by looking at Rebecca of Sunnybrook Farm, Amarilly of Clothes Line Alley, and The Love Light? It is hard to say how Marion and Pickford developed certain beliefs about the world and humanity, or what experiences they had growing up that shaped their views about humankind. Nevertheless, it can safely be said that Marion and Pickford shared values. They used film together to promote these values. It can also be said that film industry people and the general public were attracted to the messages in these pictures, which is one reason for why some of them were successful and Pickford became popular. Marion and Pickford having shared values and finding success in spreading them would certainly strengthen their friendship. Marion did think very highly of Pickford, which is evident from

\footnotetext{
${ }^{47}$ Frances Marion's The Love Light.
} 
Rebecca of Sunnybrook Farm, Amarilly of Clothes-Line Alley, and The Love Light. Marion portrayed Pickford in these films as a heroine and as a symbol of goodness. She depicts Pickford in Rebecca of Sunnybrook Farm as someone capable of becoming a better person by helping to make other people happy. Marion shows Pickford in Amarilly as representing the idea that someone can be happy and find fulfillment in their lives by being a member of the working class. In The Love Light, Marion portrays Pickford as a woman trying to hold her community together and keep it strong during the era of World War I. It can be stated that Marion strengthened Pickford's career by writing her strong roles. Furthermore, Marion's own career most likely benefited by giving Pickford heroic characters.

Pickford grew to dislike the purity she was representing on screen, which is evident in a film she and Marion made in 1920 called Pollyana. Marion stated in her autobiography Off With Their Heads! A Serio-Comic Tale Of Hollywood that making Pollyana was a dull routine, and that she and Pickford felt the film was "nauseating." Marion further stated that she hated writing Pollyana and that Pickford hated playing the character. ${ }^{48}$ Pickford stated in her own autobiography called Sunshine and Shadow why she hated playing Pollyana. She recalled getting sick of the character while making the film in 1919. Pickford hated the character of Pollyana because she was "saintly" and thus "too good to be true." In other words, Pickford disliked her character Pollyana because she was too pure. Pickford also recalled that she rebelled against the character because she was too pure to be like a real person. People in the real world are not saintly like Pollyana,

\footnotetext{
${ }^{48}$ Frances Marion, Off With Their Heads! A Serio-Comic Tale of Hollywood (New York, The Macmillan Company, 1972), 66-67.
} 
and therefore the character is unrealistic. Pickford stated that Pollyana remains saintly through out the script, and is never given the chance to change into a less saintly and more realistic person. Pickford stated that she hated the idea of "unrelieved goodness." She decided to rebel against Pollyana's purity by squashing a fly while the cameras were filming her. She scraped up a fly on a table one day while the cameras were rolling and said to it, "little fly, do you want to go to heaven?" She then smacked both her hands together and said to the smashed fly, "you have!" Pickford stated that although smashing the fly was not in the script, it remained in the film. It was Pickford's way of escaping purity. ${ }^{40}$ It is unclear from Marion's autobiography Off With Their Heads and Pickford's autobiography Sunshine and Shadow why they did Pollyanna. Despite the lack of historical research done on the relationship between Pickford and Marion, it is apparent that their friendship led them to work hard and that this is one reason for how they survived the film industry. This becomes most evident in their making of Rebecca of Sunnybrook Farm and A Poor Little Rich Girl.

\footnotetext{
${ }^{49}$ Mary Pickford, Sunshine and Shadow (Garden City, Doubleday \& Company, Inc., 1955), 191-192.
} 


\section{Chapter 4: The Hard Work of Filmmaking}

Marion stated in Off With Their Heads! that she was the grandchild of four pioneers. She was implying that like her grandparents, she also had the ability to build for herself a future in the United States and a desire to succeed. This reveals that Marion was willing to work hard to achieve something. Pickford's first husband Owen Moore had seen some poster work created by Marion. He met Marion at a New Year's Eve party and invited her to have an interview with Pickford. Moore thought that Marion might be able to create some posters for Pickford. Marion started to feel that she had a future in the movie business. Pickford took an instant liking to Marion when meeting her. Marion stated that Pickford was not looking at her outer appearance. She was trying to understand who Marion was as a person. Pickford said to Marion when shaking her hand, "I think we're going to be friends." Pickford turned out to also have a desire to succeed and was eager for hard work. Marion told Pickford that she paints and that it was hard work. Pickford replied to Marion by saying that if you want to succeed, you must work hard. Pickford went on to describe her daily routine of hard work. She stated that she and the other filmmakers work under demanding conditions in the hot sun all day. Pickford stated to Marion that as an actress, it is hard to play characters that have different personalities than her own. In other words, it is hard work to spend a day pretending like you have a different personality than the one you possess. It is difficult to play a character that is dissimilar from yourself, and therefore may be hard to understand or relate to. Pickford went on to state that as a child she tried to escape from reality and live in 
a dream world. She learned to accept reality as an adult, which means that she finally realized that the only way to survive in the difficult but real world was to work hard. ${ }^{50}$

Pickford had realized that chance is one reason for why people are cast in films as Marion noted in Off With Their Heads. If people are being cast for a film, and some unknown person that would fit a role perfectly so happens to be present or shows up in some form or another, they could get cast in the part and become a star. Marion shows in her autobiography that this was especially true about $\mathrm{ZaSu}$ Pitts when being cast alongside Pickford in A Little Princess. Marion noted, however, that Pickford knew that hard work also plays an important role in how an actor becomes successful. Rebecca of Sunnybrook Farm was hard work for Marion and Pickford. Marion stated that they went through weeks of constant grind in making the film and they were pretty tired when completing it. ${ }^{51}$ Cari Beauchamp stated that Rebecca of Sunnybrook Farm was the toughest work they did. Marion and Pickford had successfully made the film because they were extremely disciplined as Beauchamp states in Without Lying Down. Beauchamp notes that they would work every day in studio from the early morning to late at night. Marion and Pickford would arrive in the studio in the early morning and assess the work they did the previous evening. They also would study and review scripts for each day, and make sure the sets and costumes were ready for every day's work. Beauchamp noted that Rebecca's director Marshal Neilan worked well with Marion and Pickford and helped them create an "atmosphere of

\footnotetext{
${ }^{50}$ Frances Marion, Off With Their Heads!, 8-10.

${ }^{51}$ Ibid., 49-50.
} 
equality" on the set. ${ }^{52}$ Marion noted in Off With Their Heads a comment that Pickford made about hard work around the time they made Rebecca. Pickford spoke about how the general public believes mistakenly see film stars as people that went from "rags to riches" only by chance. Although chance can lead an actor to become a star as is made clear in Marion's autobiography, Pickford meant that hard work also leads an actor to achieve success. ${ }^{53}$ Pickford stated in her autobiography Sunshine and Shadow that she had demanded that Frances Marion work with her on Rebecca of Sunnybrook Farm. Pickford most likely meant that she knew Marion would work well with her. Rebecca of Sunnybrook Farm became a success for Pickford. Pickford stated in Sunshine and Shadow that Rebecca along with A Poor Little Rich Girl "gained back the ground I had lost.,"54

Pickford suffered a slump in her career before making A Poor Little Rich Girl and Rebecca of Sunnybrook Farm. She was looking for a film in which she could play a little girl again in hopes that her career would be strengthened. $A$ Poor Little Rich Girl became the first of the two films that she and Marion would make. Marion stated in Off With Their Heads that they all felt seriously about making another successful film for Pickford. They hoped that A Poor Little Rich Girl would become that success. ${ }^{55}$ According to Marion, a problem emerged after they completed A Poor Little Rich Girl. The film was screened for studio personnel. The members of the studio hated the film and called it "putrid." They did not want to release the picture in fear that it would further damage Pickford's career. The bosses of the studio considered shelving the film and creating a new

${ }^{52}$ Cari Beauchamp, Without Lying Down, 72-73.

${ }^{53}$ Frances Marion, Off With Their Heads, 49-50.

${ }^{54}$ Mary Pickford, Sunshine and Shadow, 184.

${ }^{55}$ Frances Marion, Off With Their Heads, 43. 
scenario. The makers of the film including Marion and Pickford were shocked at the news that A Poor Little Rich Girl was screened for the studio's personnel who detested it. Marion stated that everyone who had been worried about the making of the picture wanted to escape form this enormous disappointment. ${ }^{56}$ Pickford recalled in her autobiography Sunshine and Shadow that she and Marion thought they had made a "masterpiece of comedy" when finishing it. She stated, however, that the Paramount officials who screened A Poor Little Rich Girl did not think it was funny, namely the scenes that she and Marion thought were hilarious. Pickford called the day that A Poor Little Rich Girl was screened for studio officials as "one of the blackest days of my life.," ${ }^{, 57}$ Pickford stated that it gave her much anxiety about her career, and also noted that Marion felt that she had "ruined Mary's career." ${ }^{, 58}$ Marion does state in Off With Their Heads that although studio bosses were talking about not releasing the film, she and Pickford hurried $A$ Poor Little Rich Girl into the editing room in hopes of saving it. She states that they chopped out scenes to "sharpen the comedy." Pickford were eager to work extra hard to save their film. Their additional hard work paid off. Marion noted that the company decided to release A Poor Little Rich Girl and it opened at the Strand on Broadway. Marion called the company's decision the "darkest moment" for her and Pickford. Marion states, however, that she and Pickford attended the screening and were surprised to discover that the audience were laughing during the film's humorous scenes and crying during its

\footnotetext{
${ }^{56}$ Ibid., 44.

${ }^{57}$ Mary Pickford, Sunshine and Shadow, 179-180.

${ }^{58}$ Ibid., 180-181.

${ }^{59}$ Frances Marion, Off With Their Heads, 44.
} 
dramatic moments. She and Pickford realized the film was a hit. ${ }^{60}$ Pickford stated in Sunshine and Shadow that she awakened one morning to find twenty-five telegrams calling A Poor Little Rich Girl a "smash success." The success of A Poor Little Rich Girl led Pickford to demand that Marion work with her on the next film, which was Rebecca of Sunnybrook Farm. ${ }^{61}$

\section{Chapter 5: Newspapers}

\footnotetext{
${ }^{60}$ Ibid.

${ }^{61}$ Mary Pickford, Sunshine and Shadow, 183-184.
} 
The press showed much interest in Pickford and Marion, both as career women and as individuals. It is not easy to get a clear picture of their working relationship from newspapers. By examining news articles, however, a few conclusions can perhaps be made about how they affected each other professionally. A Los Angeles Times article from 1917 titled A Wonderful Girl focused on Pickford's determination to get Rebecca of Sunnybrook Farm made into a film. Rebecca of Sunnybrook Farm was successful as both a book and stage play. The play was regarded as a compelling look at young womanhood. Pickford was becoming a popular star at the time the play was being performed, and she attended a show. Pickford fell in love with the character of Rebecca and the story, so she tried to get the producers of the Biograph Company to obtain the rights to the story in hopes of making it into a film. Kate Douglas Wiggin, who wrote Rebecca of Sunnybrook Farm, refused to consent to a film adaptation of her story. This did not stop Pickford from fighting to get the picture made. She spent nine years trying to convince Wiggin to sell the rights to Rebecca of Sunnybrook Farm. Pickford tried making offers with Wiggin to increase the purchase price, but the author was not persuaded by Pickford's proposition of a wonderful sum. Kate Wiggin eventually decided that Pickford could perfectly play Rebecca. She came to believe that Pickford would immortalize her character. Pickford was finally able to get Kate Wiggin to sell the rights to Rebecca of Sunnybrook Farm. The article noted that Marion adapted the book by Kate Wiggin to the screen. It also stated that Pickford considered Rebecca of Sunnybrook Farm to be her best work to date. ${ }^{62}$

62 “A Wonderful Girl,” Los Angeles Times, 2 September 1917, III17. 
Another article from The Los Angeles Times shows why Pickford viewed the character of Rebecca as appealing. The article helps us understand Pickford as a person and as an actress. Pickford fit into the role of Rebecca easily, perfectly, and without any difficulty. Pickford had such a strong understanding of Rebecca that one could say they were like the same person. Pickford stated to a newspaperman that in playing Rebecca, there was less for her to do because the role was more real than other acting parts. Pickford found it more challenging to play artificial characters. She had a harder time understanding them because they did not resemble her. Pickford could identify with Rebecca. She found the little country girl more real and easier to play. Pickford stated to the newspaperman that playing Rebecca required "little study, so little effort and "acting" the part seemed to fit my own natural mood most perfectly." Pickford went on to say that she enjoyed making Rebecca because it was a pleasant experience. ${ }^{63}$

Marion helped Mary by writing the script for Rebecca of Sunnybrook Farm. Marion helped bring a character to life, which was similar to Pickford, and that Pickford loved and understood. Rebecca is like Pickford in how she feels, thinks, and behaves. Marion most likely gained a greater knowledge and understanding of Pickford by adapting Rebecca of Sunnybrook Farm to the screen. This would have brought her closer to Pickford.

An article from the Los Angeles Times in 1918 about Pickford's film Johanna Enlists is particularly helpful. It gives us a good idea of how important Marion was to Pickford. The article raises the question of what Pickford was going to do with her career after Marion went to France. It became clear that

${ }^{63}$ "She Loves Rebecca," Los Angeles Times, 9 September 1917, III3. 
Marion was the perfect person to write screenplays for Pickford. This is because Marion understood Pickford. Since Marion went to France, the possibility that Pickford could not find a screenwriter who understood her as well as Marion was great and certainly a concern.

The author of the article wondered that since Marion had gone to France, where was Pickford going to get scenarios for future films and who would write them? The article stated that Marion was a brilliant writer who spent five years creating comedies for Pickford that were bright, clever, and tenderly examined human nature. The press in thinking highly of these comedies suggests that they appealed to the general public and were successful. Furthermore, Marion knew all of Pickford's strengths as an actress, and she never allowed herself to forget them. Marion knew what characters Pickford could play well. Whenever Marion read stories, she was able to spot every character that not only could be played successfully by Pickford, but also would enable Pickford to show her strengths as an actress. ${ }^{64}$ The article shows that the press recognized Marion as being essential to Pickford's career. Marion helped to toughen Pickford's acting and career by writing roles for her that she understood.

Marion had gone to France to make a propaganda film for the Americans. A 1918 article in the Los Angeles Times titled Woman On Army's Heels stated that Marion quit a position on September 1 that allegedly gave her a five-figure yearly salary. The article pointed out that she had given up this job to produce and direct a film for the government about the work that women did during the war. The film was to be released by the United States Bureau of Films of the Committee on

\footnotetext{
${ }^{64}$ “Johanna Enlists,” Los Angeles Times, 16 September 1918, II6.
} 
Public Information. Marion did a lot of work among the wounded soldiers to gain knowledge about women's working experiences during the Great War. She also worked with the soldiers so that her drama would become a genuine documentation of the work of women during the war. Marion had gone from writing Pickford's type of photoplays to becoming the first American woman to reach the Rhine with American occupational forces when they entered Coblenz. Even though Marion was in France, she stayed in contact with Pickford. Frances sent Pickford letters to let her know how the production in France was doing. Marion wrote to Pickford about the heroism of the soldiers. She stated to Pickford that many of the soldiers were broken in body, but not in spirit. When Marion became ill with influenza, she wrote to Pickford from her bed on October 23. She affirmed to Pickford that since influenza prevented her from wearing gas masks, she could not enter dangerous areas. The article briefly discussed Marion's career with Pickford. It mentions some of the plays she wrote for Pickford which included The Poor Little Rich Girl, Stella Maris, How Could You, Jean, The Little America, M'Liss, and Amarilly of Clothesline Alley ${ }^{65}$ It can be said that Marion was partially able to build her career and become an important figure in the film industry by writing for Pickford. The article form the Los Angeles Times also noted that Marion became a newspaper reporter at the age of 16, did artwork, wrote fiction, and edited scenarios for the World Film Company. ${ }^{66}$ Marion's push to become a workingwoman, her ability to write and create art, and success did not have everything to do with her work for Pickford. Marion's film with Pickford

\footnotetext{
65 "Woman On Army's Heels-Scenario Writer For Mary Pickford with American Forces in Coblenz," Los Angeles Times, 22 December 1918, II6.

${ }^{66}$ Ibid.
} 
in 1921 called The Love Light does take place during the period of the Great War. It can safely be said that Marion was able to direct The Love Light because she gained knowledge about the war when working in France. It can further be said that Marion used what she learned in France to make the film believable. The Love Light can be seen as a way for Marion to include Pickford in her war experience even though the film was made almost two years after Marion worked in France.

\section{Conclusion}

As the film industry went from making silent films to using sound, Marion and Pickford were affected by this change differently. According to Marsha McCreadie, Marion made a successful transition from silent period to the era of sound with films like Dinner At Eight and Camille. She was described as having a good nature, being optimistic and lively, and modest. ${ }^{67}$ An interview with actor Joel McCrea reveals that Marion had a successful and productive career as a

\footnotetext{
${ }^{67}$ Marsha McCreadie, The Women Who Write the Movies (New York, Carol Publishing Group, 1994), 33.
} 
Hollywood screenwriter after working as a correspondent in Europe during World War I. She went on to write over 150 films. Marion also directed many pictures in the 1920s like The Cinema Murder in 1920. The interview affirms that Marion had won Oscars two years in a row. She won for writing the screenplays to The Big House in 1930 and The Champ in 1931. ${ }^{68}$

Pickford was not fortunate like Marion after the days of silent film. Fred Lawrence Guiles stated that Pickford and the other silent queens knew their films were failing at the box office after Universal accepted sound. According to Guiles, Pickford was the first to go despite winning an Academy Award for her first talking picture called Coquette. Pickford knew she would be rejected, and ended up retiring. She came out of retirement a few times, but continued to be rejected by the general public. ${ }^{69}$

Pickford's behavior in her later years became strange, which is most likely due to feelings of resentment for having been unable to maintain a career in the era of sound and having been rejected by her fans. Marion stated in her autobiography that Pickford became socially withdrawn. She said that Pickford became a recluse and lived in seclusion inside Pickfair. Marion further asserted that Pickford rarely saw anyone except her husband and family. ${ }^{70}$ An article in the Los Angeles Times by Ted Thackrey Jr. stated that Pickford would not leave her home, even to receive her second Academy Award in 1976 for her contribution to

\footnotetext{
${ }^{68}$ Joel McCrea, interview by Metta Hake, in Hearst, Hollywood, and San Simeon, ed. Nancy E. Loe (1988), 110.

${ }^{69}$ Fred Lawrence Guiles, Marion Davies: A Biography (New York, McGraw-Hill Book Company, 1972), 278.

${ }^{70}$ Frances Marion, Off With Their Heads, 297-298.
} 
the movie industry. She accepted the award at Pickfair. ${ }^{71}$ Pickford's behavior was also bizarre towards Marion. Eileen Whitfield stated in The Woman Who Made Hollywood that Pickford tried to "burn a bridge" with Marion. According to Whitfield, Marion attended a dinner at Pickfair in the early 1960s. When Pickford walked down the stairs and saw that Marion was among the guests, she ordered her out of the house. Whitfield said that Pickford forced Marion to leave her house because she once wrote the screenplay to Anne of Green Gables staring Mary Miles Minter. ${ }^{72}$ Marion said to Pickford in surprise that she was being ordered to leave Pickfair, "Mary, that was years ago." ${ }^{, 73}$ Nevertheless, Marion left the dinner quietly. Pickford sent Marion an unintelligible letter two days later to apologize for ordering her to leave Pickfair during the dinner party. Her letter read, “ I am terrible afraid I hurt your feelings the other evening. I so frightfully sorry and appologeties." Whitefield stated that although Marion forgave Pickford, their friendship weakened as the years went by. All they did during the coming years was send each other bouquets on their birthdays, and they wrote each other notes once in a while. ${ }^{74}$ Cari Beauchamp noted that Marion was irritated by Pickford's strange behavior. Beauchamp states, however, that Marion never stopped loving Pickford. ${ }^{75}$ Marion actually had a very positive view towards Pickford. She believed that Pickford had a wonderful and rewarding life despite being troubled in her later days. Marion stated in Off With Their Heads that Pickford survived many years of turbulence such as supporting her widowed

\footnotetext{
71 “Mary Pickford, 'America’s Sweetheart,' Was 86," Los Angeles Times, 30 May 1979, 20.

${ }^{72}$ Eileen Whitfield, Woman Who Made Hollywood, 357.

${ }^{73}$ Beauchamp, Without Lying Down, 368.

${ }^{74}$ Eileen Whitfield, Woman Who Made Hollywood, 357.

${ }^{75}$ Cari Beauchamp, Without Lying Down, 368.
} 
mother, and facing the deaths of both her mother and sister. Pickford made great efforts to come out of these difficult years, and succeeded by becoming one of the most famous women in the world. Marion further stated that after Pickford experienced many difficult years, she was finally able to live peacefully. ${ }^{76}$ Marion felt that Pickford's successes were far more important than her problems. Beauchamp notes that Marion was offended when an interviewer asked her about Pickford's battle with alcoholism. Marion said to the interviewer, "what business is it of anyone's? She gave the world so much pleasure and that's all that matters." ${ }^{, 77}$ Even though Marion was bothered by Pickford's strange behavior and lost much contact with her, it can be said that she was at peace with Pickford.

The letters between Pickford and Marion show that they continued to have a relationship into the 1960 s. Their relationship by the 1960 s is not clear since they were often separated. The most that can be known at the present time about the relationship between Pickford and Marion in their old age is that they felt a need for each other. Pickford was a family person between the late 1930s and the time of her death, so it is probably safe to say that Pickford saw Marion less during those years because she spent most of her with her family. Marion shows in her autobiography that Pickford had courage to retire from show business, and ended up marrying Charles Rogers with a small number of Mary's friends attending the wedding. The wedding occurred in the late 1930s and Marion attended it. According to Marion, however, Pickford eventually led a reclusive life at her home called Pickfair. The only people that Pickford saw often were her family including her husband Charles Rogers. Marion notes that Pickford felt happy and

\footnotetext{
${ }^{76}$ Frances Marion, Off With Their Heads, 297.

${ }^{77}$ Beauchamp, Without Lying Down, 368.
} 
peaceful being married to Charles Rogers. ${ }^{78}$ Pickford shows in her autobiography why she and Charles Rogers felt close to each. Pickford stated that Charles was a "complete introvert, aloof, and self contained." Mary pointed out that she was the opposite of her husband by being a "complete extrovert." Pickford stated that although this puts difficulties into a marriage, it nevertheless made their relationship stimulating. Most importantly, Pickford said that she and her husband went on long trips together without desiring the company of other people. Pickford stated that she cherished her happiness with Charles Rogers. ${ }^{79}$ This further demonstrates that Pickford would separate herself from Marion because she was happily married and had to spend time with her husband.

Marion's life during her later years, when she saw less of Pickford, is not entirely clear. Her autobiography called Off With Their Heads is like a history of the film industry and the people involved with it. It also ends at 1939 and 1940, and she spends less time talking about herself. Therefore, it does not give us a clear picture of what Marion did during the 1950s and 1960s when she saw Pickford less often. Marion discusses in the final chapter of her autobiography what happened to the most important silent screen stars including Pickford and Charles Chaplin, the people who worked in the industry after the silent period like Judy Garland and Mickey Rooney, and what she calls the "psychedelic cycle" which includes films like Easy Rider and Butch Cassidy and the Sundance Kid and what may be said about them in twenty or thirty years after they were produced. ${ }^{80}$ Off With Their Heads gives us a sense that Marion was more

\footnotetext{
${ }^{78}$ Marion, Off With Their Heads, 282, 297-298.

${ }^{79}$ Pickford, Sunshine and Shadow, 347.

${ }^{80}$ Marion, Off With Their Heads, 297, 305, 327-328.
} 
interested in the industry of Hollywood than her own life. It does not give us much information about the relationship between her and Pickford in their old age. 


\section{Bibliography}

Acker, Ally. Reel Women: Pioneers of the Cinema 1896 to the Present. New York, Continuum, 1991.

Andrews, Bob and Irene, to Buddy Rogers, 10 October. Special Collections, Margaret Herrick Library, Academy of Motion Pictures Arts and Sciences, Beverly Hills.

Andrews, Bob to Miss Helm, 19 January 1973. Special Collections, Margaret Herrick Library, Academy of Motion Pictures Arts and Sciences, Beverly Hills.

Beauchamp, Cari. Without Lying Down: Frances Marion and the Powerful Women of Early Hollywood. Berkeley, University of California Press, 1997.

Coward, Marjorie Rosen. Popcorn Venus-Women, Movies and the American Dream. New York, McCan and Geoghegan, 1973.

Finley, Harry to Mrs. Rogers. Special Collections, Margaret Herrick Library, Academy of Motion Pictures Arts and Sciences, Beverly Hills.

Francke, Lizzie. Script Girls-Women Screenwriters In Hollywood. London, British Film Institute Publishing, 1994.

Guiles, Fred Lawrence. Marion Davies: A Biography. New York, McGraw-Hill Book Company, 1972.

Holliday, Wendy." Hollywood's Modern Women: Screenwriting, Work, Culture, and Feminism, 1910-1940.” Ph.D. diss., New York University, 1995.

Holmes, Sean P. "The Hollywood Star System and the Regulation of Actor's Labor, 1916-1934." Film History 12, no. 1 (2001), pp. 97-114.

“Johanna Enlists,” Los Angeles Times, (September 16, 1918), p. 116.

Maher, Karen Ward. "Women, Filmmaking, and the Gendering of the American Film Industry, 1896-1928.” Ph.D. diss., University of Southern California, 1995.

Marion, Frances. How To Write and Sell Film Stories. New York, Garland Publishing, Inc., 1937.

Marion, Frances. The Love Light.

Marion, Frances to Mary Pickford, 1965. Special Collections, Margaret Herrick Library, Academy of Motion Pictures Arts and Sciences, Beverly Hills.

Marion, Frances to Mary Pickford and Buddy Rogers, 5 January 1967. Special Collections, Margaret Herrick Library, Academy of Motion Pictures Arts and Sciences, Beverly Hills. 
Marion, Frances to Mary Pickford, 28 January 1968. Special Collections, Margaret Herrick Library, Academy of Motion Pictures Arts and Sciences, Beverly Hills.

Marion Frances to Mary Pickford, 17 December 1969. Special Collections, Margaret Herrick Library, Academy of Motion Pictures Arts and Sciences, Beverly Hills.

Marion, Frances. Off With Their Heads! A Serio-Comic Tale of Hollywood. New York, The Macmillan Company, 1972.

“Mary Pickford, 'America’s Sweetheart,' Was 86,” (May 30, 1979), p. 20.

McCrea, Joel. "Hearst, Hollywood, and San Simeon." An Interview by Metta Hake (1988).

McCreadie, Marsha. The Women Who Write the Movies. New York, Carol Publishing Group, 1994.

Neilan, Marshall. Amarilly of Clothes-Line Alley.

Neilan, Marshall. Rebecca of Sunnybrook Farm.

Pickford, Mary to Frances Marion, 11 September 1964. Special Collections, Margaret Herrick Library, Academy of Motion Pictures Arts and Sciences, Beverly Hills.

Pickford, Mary to Frances Marion, 12 May 1965. Special Collections, Margaret Herrick Library, Academy of Motion Pictures Arts and Sciences, Beverly Hills.

Pickford, Mary to Frances Marion, 24 November 1972. Special Collections, Margaret Herrick Library, Academy of Motion Pictures Arts and Sciences, Beverly Hills.

Pickford, Mary. Sunshine and Shadow. Garden City, New York, Doubleday and Company, Inc., 1955.

“She Loves Rebecca.” Los Angeles Times, (September 9, 1917), p. 1113.

Shepard, David to Mary Pickford, 13 November 1972. Special Collections, Margaret Herrick Library, Academy of Motion Pictures Arts and Sciences, Beverly Hills.

Steidel, Debra Eve. "That Her Soul May Remain Pure: Women In American Silent Film.” M.A. diss., The American University, 1989.

Studlar, Gaylyn. "Oh, "Doll Divine": Mary Pickford, Masquerade, and the Pedophilic Gaze.” Camera Obscura 16, no.3 (2001), pp. 197-227.

Taradash, Daniel to Mr. Andrews, 7 December 1972. Special Collections, Margaret Herrick Library, Academy of Motion Pictures Arts and Sciences, Beverly Hills. 
To Frances Marion, 24 April 1973. Special Collections, Margaret Herrick Library, Academy of Motion Pictures Arts and Sciences, Beverly Hills.

To Frances Marion, 16 May 1972. Special Collections, Margaret Herrick Library, Academy of Motion Pictures Arts and Sciences, Beverly Hills.

To Frances Marion, 20 September 1972. Special Collections, Margaret Herrick Library, Academy of Motion Pictures Arts and Sciences, Beverly Hills.

To Mr. Rogers, 5 May 1972. Special Collections, Margaret Herrick Library, Academy of Motion Pictures Arts and Sciences, Beverly Hills.

Whitefield, Eileen. Pickford: The Woman Who Made Hollywood. The University Press of Kentucky, 1997.

"Woman On Army's Heels-Scenario Writer For Mary Pickford With American Forces in Coblenz." Los Angeles Times, (December 22, 1918), p. 116.

“Wonderful Girl, A.” Los Angeles Times, (September 2, 1917), p. 1111. 